УДК 004.42

DOI: https://doi.org/10.26642/ten-2020-1(85)-110-114

\author{
О.І. Грабар, к.т.н., доц. \\ А.В. Морозов, к.т.н., доц. \\ Державний університет «Житомирська політехніка»
}

\title{
Аналіз та моделювання методів вимірювання зміни швидкості психологічної реакції людини на рухомі об’скти для використання у розробці arcade-подібної гри
}

\begin{abstract}
Під час досліджень було розглянуто методи простої сенсомоторної реакиії, метод реакиії вибору, метод реакиії розрізнення, метод Штенберга та метод «ментального обертання» для визначення найефективнішого використання у програмному забезпеченні. На основі иього аналізу розроблено програмний інтерфейс для аrсаdе-подібної гри. Проаналізовано зміни швидкості реакиії користувача на рухомі об’єкти та можливість їх кореляції. Моделювання змін швидкості психологічної реакиії користувача дозволяе використання цьього програмного продукту для покращення навчання, тренування спортсменів тощяо.
\end{abstract}

Ключові слова: швидкість реакиії; агсаде-подібна гра; проєктування інтерфейсів.

Актуальність теми дослідження. Бурхливий розвиток ІТ-технологій дозволив індустрії інтерактивних розваг набути широкої популярності. За відеоіграми кожного дня проводять свій час більше ніж 15 мільйонів людей у світі, їх середній вік становить 35 років. В основному відеоігри виконують розважальну функцію, але широка популярність відносно нового виду діяльності спонукає на більш детальне дослідження впливу цього явища на когнітивні здібності мозку людини та розгляд нових способів використання відеоігор, в тому числі як навчальних.

Історія ігрової індустрії почалася в 1971 році з запуску arcade-подібної гри «Computer Space» [1]. Авторами цієї гри були Нолан Бушнелл та Тед Дабні. «Computer Space» була розвитком ідеї гри Стіва Рассела «Spacewar!», яка вийшла трохи раніше: два гравці керували невеликими космічними кораблями, а метою було збити корабель суперника. Той, хто за 99 секунд збивав ворога більшу кількість разів, ставав переможцем. Гра була складною з точки зору управління, оскільки вимагала залучення двох клавіш обертання, а також клавіш для прискорення, пострілу та гіперстрибків [2]. Ключовим моментом для розвитку електронних ігор було те, що «Computer Space» стала першою грою для arcade-подібних машин, призначеною для комерційного використання [3]. На той час ігрові arcade-подібні автомати виконували лише розважальну функцію для споживача. Але у подальшому почали з'являтися та розвиватися нові технології, жанри, ігрові системи, платформи. Таким чином ігрова індустрія стала рушійною силою розвитку комп'ютерних технологій, які згодом почали застосовуватися для інших цілей. Сучасні персональні комп’ютери мають безліч нововведень завдяки ігровій індустрії. До найбільш значущих належать звукові та графічні карти, CD- i DVD-приводи, Unix та центральні процесори. Звукові картки спочатку були розроблені для інтеграції якісного цифрового звуку в комп'ютерних іграх [4]. Система ігрової галузі індустріально підтримує виробництво центральних процесорів та інших компонентів ПК, тому що ігри потребують більш високих апаратних потужностей, ніж бізнес-додатки.

Більшість людей грають у відеоігри для того, щоб позбутися нудьги або стресу. Також онлайн-ігри допомагають людям соціалізуватися та заводити нових друзів 3 різних куточків світу. Сам ігровий процес приваблює тим, що має низький штраф за провал та високу винагороду за успіх, на відміну від реального життя. Гравцю подобається процес вирішення проблем, що йому пропонує гра. Мозок людини однаково сприймає досягнення успіху як в реальному житті, так і у віртуальному світі будь-якої відеогри [5]. Це означає, що мозок буде винагороджувати особу дозою дофаміну в будь-якому випадку. Дофамін це нейромедіатор, який відповідає за рухову активність і дарує радість руху, дає відчуття захоплення від вивчення нового. Також дофамін виконує важливу функцію винагороди та підкріплення мотивації, тобто почуття задоволеності [6-7]. Граючи, людина набагато швидше зосереджується на вирішенні складних завдань [8-10], тобто відеоігри можуть стати потужним інструментом для системи освіти.

Метою і завданням дослідження $є$ аналіз впливу відеоігор на когнітивні здібності мозку людини та подальшого використання результатів дослідження для розробки та впровадження системи тренування реакції користувача в розробці arcade-подібного тренажера.

Об'єктом дослідження $\epsilon$ розробка та реалізація arcade-подібного тренажера для подальшого дослідження зміни психологічної реакції користувача на рухомі об'єкти у цьому програмному продукті.

Предметом дослідження є моделювання зміни швидкості реакції користувача на рухомі об'єкти в arcade-подібних тренажерах.

(C) O.I. Грабар, А.В. Морозов, 2020 
Методами дослідження є сучасні методи та технології дослідження впливу відеоігор на мозок людини, метод ментальної хронометрії, методи об'єктно-орієнтованого проєктування та програмування, методи розробки дизайну інтерфейсу програмного продукту.

Викладення основного матеріалу дослідження. Наразі багато закладів освіти використовує відеоігри: щоб навчити учнів початкових класів алфавіту та правопису, для викладання понять, пов'язаних 3 математикою та наукою, використовують відеоігри, щоб вивчити іноземну мову тощо. Інший спосіб впливу відеоігор на суспільство - їх здатність навчати людей для спеціалізованих робочих місць. Технологія відеоігор використовується для створення тренажерів польотів, де майбутні пілоти тренуються на одній з таких машин перед навігацією у справжньому літальному апараті. Астронавти, військові сили та інженери також використовують технологію відеоігор для тренажерів, які допомагають їм пройти підготовку до роботи. Велику групу досліджень комп’ютерних ігор присвячено вивченню їх впливу на когнітивний розвиток людини: на пам'ять, увагу, мислення та інтелектуальні функції в цілому. Існують суперечливі дослідження. Загальне уявлення про те, що від комп’ютерних ігор мозок перестає нормально функціонувати, знаходиться на рівні суспільної свідомості й не зовсім узгоджується з даними досліджень.

Деякі дослідження показали, що відеоігри можуть покращити реакцію, логічне мислення і навіть зір [11-13], а просторові здібності у людей розвиваються. Саме з комп'ютерними іграми часто пов'язують те, що сьогодні відбувається зменшення гендерних відмінностей у просторових здібностях між чоловіками та жінками. Жінки, які грають у комп'ютерні ігри, так само добре справляються 3 просторовими завданнями, як і чоловіки [14]. Існують суперечливі дані про те, наскільки просторові здібності розвиваються у грі. Останні нейропсихологічні дослідження, в яких піддослідні проходили спеціально організовані ігрові сесії, свідчать про зміни в обсязі сірої речовини в області гіпокампу, тобто в зонах, які пов'язані з орієнтацією у просторі. Це спостерігається у гравців у тривимірні arcada-подібні ігри й у деяких гравців у комп’ютерні ігри жанру action. Водночас такі зміни відбуваються не 3 усіма піддослідними, а залежно від стратегії, яку вони використовують.

Існують дві глобальні стратегії орієнтації в просторі, які вирізнено у дослідженнях: орієнтація безпосередньо на просторові чинники та орієнтація на запам'ятовування, на автоматичні дії, пов'язані 3 орієнтацією в ігрових лабіринтах. Ефекти на мозок можуть кардинально різнитися залежно від переважної у людини стратегії. Однак зміни, які відбуваються в мозку випробовуваних, необов'язково впливають на поведінку в реальному житті.

В іншому нейропсихологічному дослідженні не виявлено ніяких відмінностей у мозковій активності людей, які мали великий досвід гри в комп'ютерні ігри, і людей, які взагалі не мали досвіду. Але виявлено відмінності на рівні точності виконання завдань. Гравці в комп’ютерні ігри швидше і точніше справлялися із завданнями на розпізнавання візуальних і буквених стимулів. Комп'ютерні ігри не тренують довготривалу пам'ять безпосередньо. Вони розвивають короткочасну робочу пам'ять. Існують дослідження, які свідчать про збільшення обсягу робочої пам'яті. Це безпосередньо пов'язано з тим, що гравцям необхідно робити у грі, тому що гра - досить складна діяльність, під час якої потрібно відстежувати різні показники та утримувати в голові багато інформації.

Також слід звернути увагу на низку досліджень, проведених Дафною Бавельє [15]. Дослідження показали, що комп'ютерні ігри сприяють покращенню контрастної чутливості (здатність розрізняти більше відтінків сірого). Також спостерігалося покращення уваги та гостроти зору. Важливо, що не всі відеоігри мають такі ефекти. 3 метою дослідження навичок поки що action-ігри приносять більше переваг, аніж інші розважальні ігри. Дослідження на основі тесту Струпа свідчать, що геймери справляються 3 цим тестом набагато швидше, ніж люди, які не грають у комп'ютерні ігри. Це дає змогу зробити такий висновок: ігри покращують уважність.

Перші наукові спостереження швидкості людської реакції стали проводити астрономи на початку дев'ятнадцятого століття. Приводом послугувало те, що різні спостерігачі записували різний час перетину зіркою меридіана, хоча прилади були однакові й працювали справно. Аналіз цих даних, накопичених протягом декількох років, показав, що помилки спостерігачів не є випадковими, а характеризують індивідуальну швидкість реагування кожного спостерігача.

Справжні серйозні експерименти над швидкістю людської реакції стали проводитися в середині дев'ятнадцятого століття Германом Гельмгольцем, Зигмундом Екснером та Франциском Дондерсом. Екснер зосередив свою увагу на простій формі реакцій, що виникала у відповідь на зорові, слухові й електрошкірні сигнали й у результаті ввів у науковий обіг термін «час реакції». Дондерс зайнявся виміром більш складних психічних актів, що містять процеси розрізнення і вибору відповідної реакції між двома або п’ятьма різними подразниками. Він розробив класифікацію довільних реакцій людини та започаткував наукову дисципліну, що отримала назву «ментальна хронометрія» [16, с. 25].

Ментальна хронометрія - метод вивчення часових характеристик та закономірностей перебігу нервових процесів, який базується на визначенні часу реакції. Час реакції - часовий інтервал між початком дії подразника на організм та моментом виникнення реакції. Складається 3 трьох фаз: час проходження нервових імпульсів від рецептора до кори головного мозку; час, необхідний для 
сприйняття, аналізу, обробки імпульсу вищими нервовими центрами та виникнення відповіді на подразник у центральній нервовій системі; час для передачі відповіді (реакції) до органів, на які діяв подразник [16, с. 198]. Час реакції залежить від виду подразника (світло, звук, тиск, температура) та його інтенсивності, стану нервової системи. Зазвичай: на світло 200-250 мс, на звук 120-150 мс та на електрошкірний подразник 100-150 мс [16, с. 246]. За ступенем складності довільні реакції людини можна розділити на три класи: проста реакція, реакція розрізнення, реакція вибору.

Проста сенсомоторна реакція - це швидка відповідь наперед відомим простим рухом на раптовий сигнал, який також наперед відомий. Наприклад, людина має натискати на кнопку, як тільки з'являється звук або світло. Реакцією розрізнення називають реакцію, яка проводиться в умовах, коли людина має реагувати тільки на один 3 двох або декількох сигналів (букви, звуки, склади), а у відповідь дія повинна відбуватися тільки на один 3 них. Реакція вибору має місце також під час пред'явлення двох або декількох сигналів, але за умови, що потрібно відповідати на кожен з них своєю певною дією.

Порівнюючи швидкості простої реакції, реакції розрізнення та реакції вибору, можна помітити, що зі зростанням рівня складності реакції зростає час цієї реакції. Таким чином проста реакція є найшвидшою, а реакція вибору - найповільнішою [17, с. 95-96]. Ця затримка обумовлена включенням актів сенсорного розрізнення і вибору відповідної реакції. Час, необхідний для розрізнення, варіює у досить широких межах.

Існує декілька основних методів для вимірювання часу реакції: метод простої сенсомоторної реакції, метод реакції вибору, метод реакції розрізнення, метод Штенберга, метод «ментального обертання». Під час використання методу простої сенсомоторної реакції суб'єкт має натискати на кнопку, як тільки з'являється або звук, або світло тощо. Метод реакції вибору досліджує швидкість різних відповідей для кожного типу подразника. Наприклад, при появі зеленого світла, натискати ліву кнопку миші, а синього - праву. Метод реакції розрізнення пов'язаний з дією чи бездіяльністю. При появі одного стимулу обстежуваний має сформувати відповідь на подразник, а другого - не реагувати. Метод Штенберга опирається на процес пошуку інформації у пам'яті, тобто, наприклад, якщо у низці фігур присутня заздалегідь вказана фігура, то натискати ліву кнопку миші, а при відсутності такої фігури - праву. Суть методу полягає в тому, що при зростанні кількості фігур збільшується кількість процесів, які обробляє мозок.

Метод «ментального обертання» - це метод, при якому обстежуваний має визначити чи $\epsilon$ запропонована раніше фігура серед фігур, які повернуті на певний кут від нуля до 360 градусів. При будь-якому підході випробовувані в нормальних умовах роблять кілька спроб. Враховується середній час, що компенсує різницю в спробах і дає більш надійний результат. Методика вимірювання часу реакції надзвичайно проста. Вона полягає в реєстрації проміжку часу між початком дії подразника і моментом здійснення відповідної реакції тим чи іншим технічним способом. У ролі подразника зазвичай використовуються зорові сигнали, наприклад, спалахування різнокольорових лампочок. Одночасно 3 подачею сигналу вмикається прилад, що вимірює час. Випробовуваний своєю відповідною дією вимикає останній, і таким чином реєструється час реакції (ЧР).

Важливою умовою отримання достовірних результатів при вимірюванні ЧР $є$ ізоляція випробуваного від сторонніх подразників. Бажано, щоб він знаходився в окремій звукоізольованій камері, куди подаються тільки сигнальні подразники. Перед початком дослідів проводиться попереднє опитування випробуваного під час якого з'ясовується вік, освіта, стан здоров'я та рівень тренованості в досліджуваному типі реакцій. Після цього обстежуваному надається заздалегідь складена детальна інструкція дослідів. Мета інструкції полягає в тому, щоб пояснити випробуваному, в чому полягає його завдання, тобто, що і як він має робити при появі сигналів. Особливо важливо, щоб усі елементи інструкції були чітко зрозумілі та твердо засвоєні обстежуваним. Під час проведення дослідів перед кожним черговим сигналом зазвичай подається так званий попереджувальний сигнал «Увага», що дає можливість випробуваному підготуватися до очікуваного тестового сигналу і відповідної реакції. Попереджувальний сигнал може даватися або в словесній формі («є», «увага»), або у формі особливого подразника (дзвінок, спалах світла). Спеціальні дослідження показали, що найбільш ефективний інтервал між попереджувальним і тестовим сигналом дорівнює 1,5-2 с. У ситуації простої реакції, щоб уникнути вироблення умовного рефлексу на час і появи передчасних реакцій, цей інтервал слід трохи варіювати (2 с \pm 400 мс).

Завдяки науковому прогресу дисципліна не стоїть на місці, нові технології з кожним роком підвищують точність вимірювання реакції. Звичайно в цих дослідженнях вкрай зацікавлена сфера спорту: регулярні спостереження швидкості реакції гравців ведуться в футболі, тенісі, автогонках, боксі й навіть в шахах. А також ігрова індустрія в цілому.

Для розробки цього програмного продукту було обрано такі актуальні інструментальні засоби: середовище розробки ігрових програмних засобів «Unity» та мова програмування Visual C\# для написання програмного коду тренажера. Для проєкту було обрано мову Visual C\#, оскільки вона входить у трійку лідерів за популярністю в світі, постійно розвивається, має широкі межі використання та дозволяє здійснювати інтеграцію додатків різних типів [18]. Для проведення дослідження реалізовано два режими тестування: перший режим має тренувати просту сенсомоторну реакцію, другий тренує реакцію розрізнення. 
Для реалізації додатка було створено проєкт на Unity, який складається 3 трьох сцен: сцена «MainMenu» - це головне меню додатка. При завантаженні додатка на екрані в першу чергу з'являється сцена головного меню. У цій сцені є можливість обрати один із видів тестування та покинути додаток. У сценах «SingleTest» та «Multitest» реалізовано обидва види тестування.

Можливі переходи між сценами можна зобразити за допомогою діаграми активності (рис. 1):

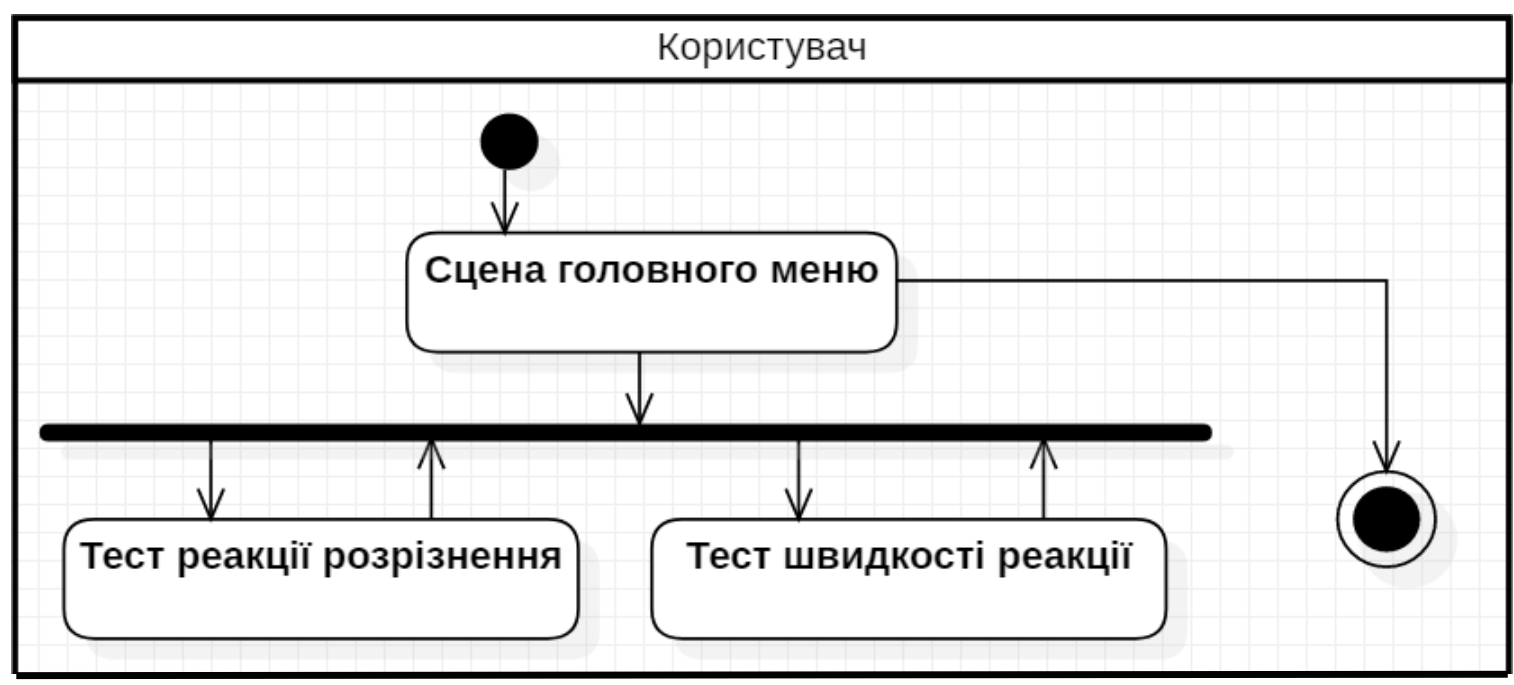

Рис. 1. Діаграма активності додатка

Після завантаження додатка користувач має змогу обрати один із запропонованих тестів чи припинити роботу додатка, натиснувши кнопку «вихід» або кнопку «Еsc» на клавіатурі. Обравши один із видів тестування, користувач перейде на відповідну сцену, де він зможе повернутися на головне меню додатка чи розпочати тестування. Можливість виходу із додатка у сценах з тестами не було реалізовано для запобігання випадкового закриття під час проведення тестування.

Висновки. У цій роботі проведено дослідження впливу відеоігор на когнітивні здібності мозку людини та на основі отриманих даних розроблено й реалізовано arcade-подібний тренажер. За його допомогою було проведено власне моделювання зміни швидкості психологічної реакції користувача на рухомі об'єкти та доведено ефективність такого тренажера. Розроблена система допомагає покращити швидкість реакції мозку на рухомі об'єкти, що дає можливість впровадити цю систему у військові установи або на підприємства, які вимагають від своїх працівників високої швидкості реакції мозку.

\section{Список використаної літератури:}

1. Индустрия компьютерных игр // Википедия. - 2019 [Електронний ресурс]. - Режим доступу : https://ru.wikipedia.org/wiki/Индустрия_компьютерных_игр.

2. Computer Space // International Arcade Museum. - 2019 [Електронний ресурс]. - Режим доступу : https://www.arcade-museum.com/game_detail.php?game_id=7381.

3. Edwards Benj Computer Space and the Dawn of the Arcade Video Game / Benj Edwards // Technologizer. - 2011 [Електронний ресурс]. - Режим доступу : https://www.technologizer.com/2011/12/11/computer-space-and-thedawn-of-the-arcade-video-game/.

4. Індустрія відеоігор // Вікіпедія. - 2019 [Електронний ресурс]. - Режим доступу : https://uk.wikipedia.org/wiki/Індустрія_відеоігор\#cite_note-3.

5. Neuronal and oscillatory activity during reward processing in the human ventral striatum / Bradley C. Lega, Michael Kahana, Jurg Jaggi and other // US National Library of Medicine National Institutes of Health. - 2011 [Електронний ресурc]. - Режим доступу : https://www.ncbi.nlm.nih.gov/pmc/articles/PMC3188759/.

6. Нейромедиаторы, часть первая: дофамин, норадреналин, серотонин // Хабр. - 2019 [Електронний ресурс]. Режим доступу : https://habr.com/ru/company/atlasbiomed/blog/397735/.

7. Nakamura Yuji Peak Video Game? Top Analyst Sees Industry Slumping in 2019 / Yuji Nakamura // Bloomberg. 2019 [Електронний ресурс]. - Режим доступу : https://www.bloomberg.com/news/articles/2019-01-23/peakvideo-game-top-analyst-sees-industry-slumping-in-2019.

8. Cyberathlete Professional League // Вікіпедія. - 2019 [Електронний ресурс]. - Режим доступу : https://ru.wikipedia.org/wiki/Cyberathlete_Professional_League.

9. Киберспорт // Вікіпедія. - 2019 [Електронний ресурс]. - Режим доступу https://ru.wikipedia.org/wiki/Киберспорт.

10. The International 2018 // Вікіпедія. - 2019 [Електронний ресурс]. - Режим доступу : https://ru.wikipedia.org/wiki/The_International_2018. 
11. Przybylski Andrew K. Violent video game engagement is not associated with adolescents' aggressive behaviour: evidence from a registered report / Andrew K. Przybylski, Netta Weinstein // The royal society publishing. - 2019 [Електронний ресурс]. - Режим доступу : https://royalsocietypublishing.org/doi/10.1098/rsos.171474.

12. Feng Jing Playing an Action Video Game Reduces Gender Differences in Spatial Cognition / Jing Feng, Ian Spence, Jay Pratt // Sage journals. - 2007 [Електронний ресурс]. - Режим доступу : https://journals.sagepub.com/doi/abs/10.1111/j.1467-9280.2007.01990.x.

13. Daphne Bavelier // Вікіпедія. - 2019 [Електронний ресурс]. - Режим доступу : https://en.wikipedia.org/wiki/Daphne_Bavelier.

14. Ментальна хронометрія // Вікіпедія. - 2019 [Електронний ресурс]. - Режим доступу : https://uk.wikipedia.org/wiki/Ментальна_хронометрія.

15. Jensen A. Clocking the mind: Mental Chronometry and Individual Differences. / A.Jensen // Elsevier. - 2006.

16. Платонов К. Занимательная психология / К.Платонов. - М. : Молодая гвардия, 1964. - 384 с.

17. Bartz Albert E. Reaction time as a function of stimulus uncertainty on a single trial / Albert E. Bartz // Perception \& Psychophysics. - 1971. - C. 95-96.

18. Unity // Вікіпедія. - 2019 [Електронний ресурс]. - Режим доступу : https://uk.wikipedia.org/wiki/Unity_(рушій_гри).

\section{References:}

1. Vikipedija (2019), «Industrija komp'juternyh igr», [Online], available at: https://ru.wikipedia.org/wiki/ Industrija_komp'juternyh_igr

2. International Arcade Museum (2019), «Computer Space», [Online], available at: https://www.arcademuseum.com/game_detail.php?game_id=7381

3. Edwards, Benj (2011), «Computer Space and the Dawn of the Arcade Video Game», Technologize [Online], available at: https://www.technologizer.com/2011/12/11/computer-space-and-the-dawn-of-the-arcade-video-game/

4. Vikipedija (2019), «Industrija videoigor», [Online], available at: https://uk.wikipedia.org/wiki/Industrija_videoigor\#cite_note-3

5. Lega, Bradley C., Kahana, Michael, Jaggi, Jurg and other (2011), «Neuronal and oscillatory activity during reward processing in the human ventral striatum», US National Library of Medicine National Institutes of Health, [Online], available at: https://www.ncbi.nlm.nih.gov/pmc/articles/PMC3188759/

6. Habr (2019), «Nejromediatory, chast' pervaja: dofamin, noradrenalin, serotonin», [Online], available at: https://habr.com/ru/company/atlasbiomed/blog/397735/

7. Nakamura, Yuji (2019), «Peak Video Game? Top Analyst Sees Industry Slumping in 2019», Bloomberg, [Online], available at: https://www.bloomberg.com/news/articles/2019-01-23/peak-video-game-top-analyst-sees-industryslumping-in-2019

8. Vikipedija (2019), «Cyberathlete Professional League», [Online], available at: https://ru.wikipedia.org/wiki/Cyberathlete_Professional_League

9. Vikipedija (2019), «Kybersport», [Online], available at: https://ru.wikipedia.org/wiki/Kybersport

10. Vikipedija (2019), «The International 2018», [Online], available at: https://ru.wikipedia.org/wiki/The_International_2018

11. Przybylski, Andrew K. and Weinstein, Netta (2019), «Violent video game engagement is not associated with adolescents' aggressive behaviour: evidence from a registered report», The royal society publishing, [Online], available at: https://royalsocietypublishing.org/doi/10.1098/rsos.171474

12. Feng, Jing, Spence, Ian and Pratt, Jay (2007), «Playing an Action Video Game Reduces Gender Differences in Spatial Cognition», Sage journals, [Online], available at: https://journals.sagepub.com/doi/abs/10.1111/j.14679280.2007.01990.x

13. Vikipedija (2019), «Daphne Bavelier», [Online], available at: https://en.wikipedia.org/wiki/Daphne_Bavelier

14. Vikipedija (2019), «Mental'na hronometrija», [Online], available at: https://uk.wikipedia.org/wiki/Mental'na_hronometrija

15. Jensen, A. (2006), «Clocking the mind: Mental Chronometry and Individual Differences», Elsevier.

16. Platonov, K. (1964), Zanimatel'naja psihologija, Molodaja gvardija, M., 384 p.

17. Bartz, Albert E. (1971), «Reaction time as a function of stimulus uncertainty on a single trial», Perception \& Psychophysics, pp. 95-96.

18. Vikipedija (2019), «Unity», [Online], available at: https://uk.wikipedia.org/wiki/Unity_(rushij_gry)

Грабар Ольга Іванівна - кандидат технічних наук, доцент кафедри інженерії програмного забезпечення Державного університету «Житомирська політехніка».

Наукові інтереси:

- програмна інженерія; синергетика систем;

- $\quad$ математичне моделювання; розробка інтерфейсів програмного забезпечення.

E-mail: grabar-olga@ztu.edu.ua.

Морозов Андрій Васильович - проректор, кандидат технічних наук, доцент кафедри комп'ютерних наук Державного університету «Житомирська політехніка».

Наукові інтереси:

- інформаційні технології; математичне моделювання.

E-mail:morozov@ztu.edu.ua. 